\title{
Comparison of preoperative endometrial biopsy grade and final pathologic diagnosis in patients with endometrioid endometrial cancer
}

\author{
Endometrioid endometriyum kanserli olgularda preoperatif endometriyal biyopsi \\ grade ile postoperatif patolojik değerlendirmenin karşılaştırılması
}

\author{
Behiye Pınar Çilesiz Göksedef ${ }^{1}$, Özgür Akbayır ${ }^{2}$, Aytül Çorbacıŏlu' ${ }^{2}$, Hakan Güraslan², Fatmagül Şencan², Onur Erol ${ }^{3}$, Ahmet Çetin ${ }^{1}$ \\ 'Department of Gynecology and Obstetrics, Haseki Teaching and Research Hospital, Istanbul, Turkey \\ ${ }^{2}$ Department of Gynecology and Obstetrics, Istanbul Kanuni Sultan Süleyman Research and Teacing Hospital, istanbul, Turkey \\ ${ }^{3}$ Department of Gynecology and Obstetrics, Antalya Teaching and Research Hospital, Antalya, Turkey
}

\section{Abstract}

Objective: To compare preoperative grading in endometrioid endometrial cancer with the final pathologic assessment of the hysterectomy specimen. The second objective of the study was to determine a high risk group who will be upgraded in the postoperative evaluation.

Material and Methods: A total of 335 patients with endometrioid endometrial cancer were retrospectively reviewed between June 2000 and January 2011. All pathology results were pre- and postoperatively reviewed at two institutions, and all patients underwent surgical therapy. Sensitivity, specificity, positive and negative predictive values and accuracy rates were calculated for all grades in the preoperative assessment.

Results: The mean age of the patients was $56.2 \pm 9.6$ and the vast majority of the patients were postmenopausal ( $n=239,71.3 \%)$. FIGO grade was determined to be greater in 75 patients in the final hysterectomy specimen. Fifty-five (32.9\%) of the patients with preoperative grade 1 were found to be grade 2 and $3.6 \%$ of them were upgraded to grade 3 . Fourteen of the patients with grade $2(11.4 \%)$ were found to be grade 3 . The accuracy rates of the preoperative grade assessment with endometrial sampling were $75.5 \%, 66.2 \%$ and $88.3 \%$ for grades 1 , 2 and 3 , respectively. There were no statistically significant differences in the preoperative demographic characteristics between patients with or without upgraded tumors.

Conclusion: A high percentage of preoperatively diagnosed grade 1 tumors were upgraded in the postoperative evaluation. The patients who would have been upgraded after hysterectomy could not have been predicted preoperatively using the characteristic features.

(J Turkish-German Gynecol Assoc 2012; 13: 106-10)

Key words: Endometrial cancer, biopsy, grade, preoperative evaluation, postoperative evaluation

Received: 15 January, 2012

Accepted: 22 March, 2012

\section{Ozzet}

Amaç: Endometrioid tip endometriyum kanserinde preoperatif ve postoperatif histerektomi materyalindeki grade'in karşılaştırılmasıdır. İkinci amaç ise postoperatif değerlendirmede upgrade olabilecek yüksek riskli grubun tanımlanmasıdır.

Gereç ve Yöntemler: Haziran 2000 ve Ocak 2011 tarihleri arasında endometrioid tip endometriyum kanserli 335 olgu retrospektif olarak incelendi. Tüm patolojik sonuçlar pre ve postoperatif olarak aynı merkezlerde değerlendirilerek, tüm olgulara cerrahi yapıldı. Preoperatif grade için sensitivite, spesifisite, pozitif ve negatif prediktif değerler ve doğruluk oranları hesaplandı.

Bulgular: Ortalama yaş $56.2 \pm 9.6$ idi ve olguların çoğunluğu postmenapozal idi ( $n=239, \% 71.3)$. Olguların 75'i histerektomi spesmeninde daha yüksek grade'li olarak saptandı. Preoperatif grade 1 saptanan 55 olgu (\%32.9) postoperatif olarak grade 2 saptanırken \%3.6 olgu grade 3 tespit edildi. Grade 2 saptanan 14 olgu (\%11.4) postoperatif olarak grade 3 saptandı. Endometriyal örnekleme ile preoperatif grade değerlendirilmesinin tanısal doğruluk oranları grade 1,2 ve 3 için sırasıyla \%75.5, \%66.2 ve \%88.3 idi. Upgrade olan ve olmayan olgular arasında demografik karakteristikler açısından istatistiksel olarak anlamlı fark bulunmadı.

Sonuç: Preoperatif olarak grade 1 tanısı almış olgularda, yüksek oranda postoperatif olarak daha yüksek bir grade saptanmaktadır. Histerektomi sonrası hangi olguların upgrade olabileceği preoperatif karakteristiklerle tahmin edilememektedir.

(J Turkish-German Gynecol Assoc 2012; 13: 106-10)

Anahtar kelimeler: Endometriyum kanseri, biyopsi, grade, preoperatif değerlendirme, postoperatif değerlendirme

Geliş Tarihi: 15 Ocak 2012

Kabul Tarihi: 22 Mart 2012

\section{Introduction}

The grade of a tumor is a well-known prognostic factor for women with endometrial carcinoma and correlates with the depth of myometrial invasion, lymph node involvement, surgical stage and survival $(1,2)$. The staging for endome- trial carcinoma has been suggested as a surgical-pathologic system which includes peritoneal cytology, pelvic and paraaortic lymphadenectomy (3). In 2005, the American College of Obstetricians and Gynecologists (ACOG) recommended surgical staging for women with endometrial cancer, except for young or perimenopausal women with grade 1 endo- 
metrioid adenocarcinomas, as well as atypical endometrial hyperplasia, and women at high risk of mortality secondary to comorbidities (4). The role of lymphadenectomy has not been clearly defined in the management of endometrial cancer, especially in patients with grade 1 and 2 disease that is limited in the uterus. Some authors advise performing a routine pelvic and/or para-aortic lymphadenectomy in all women (5), whereas others have questioned the clinical utility of this procedure because of the complications of lymphadenectomy, especially in patients at low risk of nodal involvement (grade 1 or 2 with no or minimal myometrial invasion) $(6,7)$.

Approximately $52 \%$ of women with endometrial carcinoma have a preoperative endometrial biopsy showing grade 1 (8). The accuracy of preoperative grading is an extremely important issue in young patients with well-differentiated endometrial carcinoma who desire future fertility and uterine preservation. In addition, preoperative endometrial biopsy is often the basis of referral to centers and most of the well-differentiated tumors are managed by general gynecologists and often without appropriate incision or surgical staging. Recently, two randomized multicenter studies reported no evidence of benefits in terms of overall or recurrence-free survival for pelvic lymphadenectomy in women with preoperative International Federation of Gynecology and Obstetrics (FIGO) stage I endometrial cancer $(9,10)$.

Most of the studies which have investigated preoperative tumor grading by various endometrial sampling methods have shown that these methods are poorly correlated with the final pathologic grade $(8,11-13)$. A higher FIGO grade on final uterine pathologic examination will be diagnosed in $24 \%$ of patients with preoperative FIGO grade 1 and the vast majority of cases will be upgraded to FIGO grade 2, but approximately $3 \%$ will be upgraded to FIGO grade 3 or be diagnosed as a serous or clear cell carcinoma on final pathologic assessment of the hysterectomy specimen (7-12). However, there are some studies that show nearly perfect agreement between preoperative and final pathologic grades $(14,15)$.

The objective of this study was to compare preoperative grading with the final pathological assessment of the hysterectomy specimen. The second objective of the study was to determine the high risk group who will be upgraded in the postoperative evaluation.

\section{Materials and Methods}

Between June 2000 and January 2011, a total of 335 patients with endometrioid endometrial cancer were reviewed retrospectively. These cases were identified from a database after approval was granted by the Institutional Review Board at the Bakirkoy Women's and Children's Teaching and Research Hospital and Haseki Teaching and Research Hospital. D\&C was used as the method of endometrial sampling in all cases. All patients underwent hysterectomy and lymphadenectomy as the primary treatment for their endometrial cancer. All of the preoperative endometrial histological examinations were performed and reviewed at these two institutions by specialized gynecologic pathologists. Only the patients with preoperatively diagnosed endometrioid endometrial carcinoma were evaluated in this study. Cases of serous or clear cell adenocarcinoma, whether alone or mixed with the other subtypes and nonepithelial histology, were excluded.

Operative reports were reviewed to determine intraoperative findings. The pathology reports of the specimens revealed the FIGO grade, the depth of myometrial invasion, the FIGO stage of disease, the presence of extra-uterine metastases, the peritoneal cytologic results and the presence of lymphvascular space invasion (LVSI). Patients were classified as upgraded if the postoperative definitive grade was determined to be a greater then the preoperative grade.

The sensitivity, specificity, positive predictive value (PPV), negative predictive value (NPV) and accuracy rates were calculated for all preoperatively assessed grades. Chi-square and Fisher's exact tests were used, as appropriate, to compare nominal variables. All statistical analyses were performed using SPSS for Windows version 15.0.1 (Chicago, IL).

\section{Results}

A total of 335 patients with endometrioid type endometrial cancer were evaluated. The mean age of the patients was 56.2 \pm 9.6 and the vast majority of the patients were postmenopausal $(n=239,71.3 \%)$. Table 1 summarizes the demographic and clinic characteristics of the patients. Most of the patients had grade 2 disease $(n=152,45.4 \%) .40 .9 \%$ and $13.7 \%$ of them had grade 1 and grade 3 disease at the final pathologic examination, respectively.

Table 2 shows the distribution of the surgical outcomes according to the preoperative grades of the patients. FIGO grade was determined to be greater in 75 patients in the final hysterectomy specimen. Fifty-five (32.9\%) of the patients with preoperative grade 1 were found to be grade 2 and $3.6 \%$ of them were

Table 1. Demographic and clinical characteristics of the patients

\begin{tabular}{|c|c|}
\hline & n (\%) \\
\hline Age (mean $\pm s d)$ & $56.2 \pm 9.6$ \\
\hline Gravida (median) & 3.0 \\
\hline Parity (median) & 3.0 \\
\hline Menopause & $239(46.0)$ \\
\hline $\mathrm{BMI} \geq 30$ & $182(35.0)$ \\
\hline $\mathrm{DM}$ & $88(16.9)$ \\
\hline HT & $142(27.3)$ \\
\hline \multicolumn{2}{|l|}{ Operation } \\
\hline TAH-BSO-PLND & $193(55.7)$ \\
\hline TAH-BSO-PPLND & $142(42.3)$ \\
\hline \multicolumn{2}{|c|}{$\begin{array}{l}\text { BMI: body mass index, DM: diabetes mellitus, HT: hypertension, TAH- } \\
\text { BSO-PLND: total abdominal hysterectomy- bilateral salphingoopherec- } \\
\text { tomy-pelvic lymph node dissection, TAH-BSO-PPLND: total abdominal } \\
\text { hysterectomy- bilateral salphingoopherectomy-pelvic and para-aortic } \\
\text { lymph node dissection }\end{array}$} \\
\hline
\end{tabular}


Table 2. Comparison of the surgical outcomes according to preoperative FIGO grade

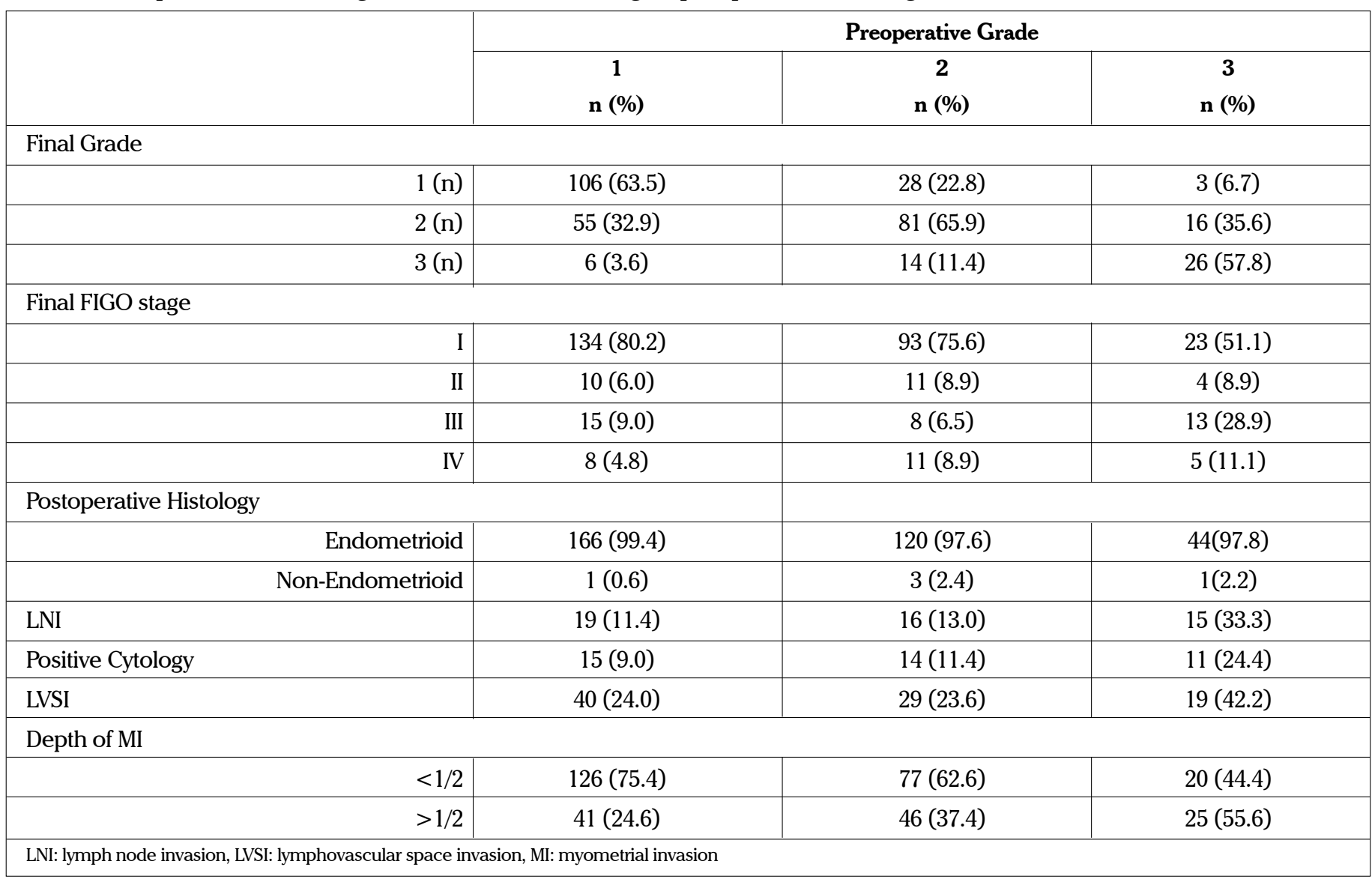

Table 3. Sensitivity, specificity, PPV and NPV for preoperative grade prediction

\begin{tabular}{|l|c|c|c|}
\hline & Grade 1 & Grade 2 & Grade 3 \\
\hline Sensitivity & $77.3 \%$ & $53.2 \%$ & $56.5 \%$ \\
\hline Specificity & $67.5 \%$ & $77.0 \%$ & $93.4 \%$ \\
\hline PPV & $63.4 \%$ & $65.8 \%$ & $57.7 \%$ \\
\hline NPV & $80.3 \%$ & $66.5 \%$ & $93.1 \%$ \\
\hline Accuracy & $75.5 \%$ & $66.2 \%$ & $88.3 \%$ \\
\hline PPV: positive predictive value, NPV: negative predictive value \\
\hline
\end{tabular}

upgraded to grade 3 . Fourteen of the patients with grade 2 (11.4\%) were found to be grade 3 .

The vast majority of the patients with preoperative grade 1 had stage I disease $(80.2 \%), 6.0 \%$ of them had stage II, $9.0 \%$ and $4.8 \%$ of the patients had stage III and IV disease. Lymph node involvement was detected in $11.4 \%$ and the depth of myometrial invasion (MI) was greater than $50 \%$ in $24.6 \%$ of the patients who had grade 1 tumors preoperatively.

The overall accuracy rate of preoperative histologic grade evaluation was $64.1 \%$. The sensitivity, specificity, PPV and NPV rates of the preoperative grade prediction are summarized in Table 3. Among the preoperatively assessed grades, grade 1 had higher sensitivity (77.3\%) and lower specificity rates (67.5\%) compared with grade 2 and grade 3 . The accuracy rates of the preoperative grade assessment with endometrial sampling were $75.5 \%$, $66.2 \%$ and $88.3 \%$ for grades 1,2 and 3, respectively.

If the patients with a preoperative diagnosis of grade 3 were excluded, $25.8 \%$ of the patients were found to have a higher grade in the final pathologic examination. A comparison of the demographic and pathologic characteristics between patients with or without upgraded cancer is summarized in Table 4 . Upgraded tumors were significantly related to a higher stage of disease $(p=0.003)$ and positive peritoneal cytology $(p=0.04)$.

\section{Discussion}

The surgical approach for endometrial cancer varies from only total hysterectomy with bilateral oophorectomy to hysterectomy with full pelvic and para-aortic lymphadenectomy. Preoperative tumor grading with pre- and/or intraoperative assessment of the depth of myometrial invasion, as well as the histologic subtype, is frequently used to decide whether lymph node dissection is necessary at the time of hysterectomy. According to FIGO guidelines, lymphadenectomy should be performed when myometrial invasion is greater than $50 \%$ and/or when the tumor is undifferentiated (16). Similarly, Mariani et al. (17) reported that patients with FIGO grade 1 or 2 endometrial cancer with macroscopically no or superficial myometrial invasion $(<50 \%)$ can be treated safely with only hysterectomy. However, pre- and 
Table 4. Univariate analysis for the patients with or without upgraded tumors

\begin{tabular}{|c|c|c|c|}
\hline & $\begin{array}{c}\text { Upgraded } \\
\text { n (\%) }\end{array}$ & $\begin{array}{c}\text { Not upgraded } \\
\text { n (\%) }\end{array}$ & $\mathbf{p}$ \\
\hline \multicolumn{4}{|l|}{ Age (years) } \\
\hline$<70$ & $72(96.0)$ & $200(93.0)$ & 0.35 \\
\hline$\geq 70$ & $3(4.0)$ & $15(7.0)$ & \\
\hline Menopause status & & & 0.88 \\
\hline Premenopausal & $22(29.3)$ & $65(30.2)$ & \\
\hline Postmenopausal & $53(70.7)$ & $150(69.8)$ & \\
\hline BMI & & & 0.19 \\
\hline$<30$ & $39(52.0)$ & $93(43.3)$ & \\
\hline$\geq 30$ & $36(48.0)$ & $122(56.7)$ & \\
\hline $\mathrm{DM}$ & $15(20.0)$ & $58(27.0)$ & 0.23 \\
\hline HT & $36(48.0)$ & $86(40.0)$ & 0.22 \\
\hline Final FIGO stage & & & $0.003^{*}$ \\
\hline I & $46(61.3)$ & $204(78.4)$ & \\
\hline II & $9(12.0)$ & $16(6.2)$ & \\
\hline III & $10(13.3)$ & $26(10.0)$ & \\
\hline IV & $10(12.3)$ & $14(5.4)$ & \\
\hline LNI & $59(78.7)$ & $226(86.9)$ & 0.07 \\
\hline Positive Cytology & $14(18.7)$ & $26(10.0)$ & 0.04 \\
\hline LVSI & $23(30.7)$ & $65(27.0)$ & 0.32 \\
\hline Depth of MI & & & 0.59 \\
\hline$<1 / 2$ & $48(64.0)$ & $175(67.3)$ & \\
\hline$>1 / 2$ & $27(36.0)$ & $85(32.7)$ & \\
\hline
\end{tabular}

intraoperative assessment of the myometrium is an inaccurate predictor of the actual depth of myometrial invasion (11). In a series of 112 patients, Frumovitz et al. (11) reported that a frozen section diagnosis of no myometrial invasion is not accurate in $72 \%$ of cases, and $26 \%$ of cases with a frozen section of myometrial invasion $<50 \%$ will actually have deeper invasion, cervical invasion and/or extra-uterine disease.

Preoperative tumor grade based on endometrial sampling is also reported to be poorly correlated with the final pathologic grade $(8,11-13,18,19)$ and a greater FIGO grade on final hysterectomy pathological assessment will be diagnosed as high as in $30 \%$ of patients with preoperative FIGO grade 1 (12). In another study, which compared histological grades between D\&C and the hysterectomy specimen in grade 1 tumors on the final hysterectomy pathological assessment showed an overall upgrade rate of $50 \%$ and a concordance rate of $32.5 \%$ (20).

On the other hand, Kang et al. (14) recently evaluated a total of 122 patients with low-risk endometrial cancer for the necessity of lymphadenectomy and showed nearly perfect agreement between pre- and postoperative grades, even when Pipelle was used for the preoperative diagnosis. Similarly, in a study with a very large series of only preoperatively detected as grade 1 endometrial cancer, almost $15 \%$ of the pathology specimens were upgraded in the final hysterectomy specimen (15).

In our study, nearly $35 \%$ of the patients with FIGO grade 1 endometrial adenocarcinoma prior to hysterectomy were diagnosed with a greater FIGO grade after hysterectomy. This finding may be explained by the fact that FIGO grading is based on the percentage of solid growth within a specimen and will therefore vary once the final specimen is obtained and a greater tissue volume is examined. In addition to this, $13.8 \%$ of the patients with preoperative grade 1 disease had advanced stage of disease (stage 3 and 4). Lymph node involvement was detected in $11.4 \%$ of the patients with preoperative grade 1 and $9 \%$ of them had positive peritoneal cytology. If the patients were selected for surgical staging according to preoperative grading, more than $10 \%$ of the patients with preoperative grade 1 would have been subjected to inappropriate surgery in our cohort. In an Italian multicenter study which evaluated the efficacy of systemic lymphadenectomy in patients with preoperative and intraoperative stage I disease, almost $25 \%$ of the total cohort was upstaged (FIGO II, III, IV) after definitive surgery and 
patients undergoing systemic lymphadenectomy had a higher likelihood of being upstaged to FIGO IIIC disease compared the no lymphadenectomy arm (13.3\% vs. 3.2\%) (10). Another randomized trial (MRC ASTEC) also showed that $23 \%$ of patients with a preoperatively diagnosed stage I tumor were upstaged in both the standard surgery and lymphadenectomy arms (11). Our second objective in conducting this study was to preoperatively determine the high risk group in which patients will be upgraded in postoperative evaluation. However, there was no statistically significant difference in the demographic and clinical features between patients with or without upgraded tumors. We found a significant relation only between the stage of disease, positive abdominal cytology and upgrading. However, those were mostly detected after surgical staging. Thus, it is not possible to predict the high risk group for upgrading preoperative findings.

In conclusion, unpredictably, a high percentage of preoperatively diagnosed as grade 1 tumors were upgraded in the postoperative evaluation. According to our study, it is not possible to say that lymphadenectomy should be considered as comprehensive surgical staging in all patients with preoperatively diagnosed endometrial cancer, but it should be mentioned that patients with a preoperative diagnosis of grade 1 uterine cancers have a risk of extra-uterine spread, and the information achieved from an appropriate surgical staging procedure affects the adjuvant treatment decision.

\section{Conflict of interest}

No conflict of interest was declared by the authors.

\section{References}

1. Creasman WT, Morrow CP, Bundy BN, Homesley HD, Graham JE, Heller PB. Surgical pathologic spread patterns of endometrial cancer. A gynecologic oncology group study. Cancer 1987; 60: 2035- 41. [CrossRef]

2. Abeler VM, Kjorstad KE. Endometrial adenocarcinoma in Norway: a study of a total population. Cancer 1991; 67: 3093-103. [CrossRef]

3. Announcement. FIGO stages: 1988 revisions. Gynecol Oncol 1989; 35: 125- 7. [CrossRef]

4. American College of Obstetricians and Gynecologists.ACOG practice bulletin, clinical management guidelines for obstetrician-gynecologists, number 65, August 2005: management of endometrial cancer.Obstet Gynecol 2005; 106: 413-25.

5. Barnes NM, Kilgore LC. Complete surgical staging of early endometrial adenocarcinoma. Optimizing patients outcomes. Semin Radiat Oncol 2000; 10: 3-7. [CrossRef]

6. Geisler JP, Wiemann MC, Zhou Z, Miller GA, Geisler HE. Using FIGO histologic grade to determine when to perform lymphadenectomies in endometrioid adenocarcinoma of the endometrium. Eur $\mathrm{J}$ Gynaecol Oncol 1996; 17: 204-7.
7. Orr Jr JW, Roland PY, Leichter D, Orr PF. Endometrial cancer: is surgical staging necessary? Curr Opin Oncol 2001; 13: 408-12. [CrossRef]

8. Ben-Shachar I, Pavelka J, Cohn DE, Copeland LJ, Ramirez N, Manolitsa T, et al. Surgical staging for patients presenting with grade 1 endometrial carcinoma. Obstet Gynecol 2005; 105: 487-93. [CrossRef]

9. ASTEC study group, Kitchener H, Swart AM, Qian Q, Amos C, Parmar MK. Efficacy of systematic pelvic lymphadenectomy in endometrial cancer (MRC ASTEC trial): a randomised study. Lancet 2009; 373: 125-36. [CrossRef]

10. Benedetti Panici P, Basile S, Maneschi F, Alberto Lissoni A, Signorelli M, Scambia G, et al. Systematic pelvic lymphadenectomy vs. no lymphadenectomy in early-stage endometrial carcinoma: randomized clinical trial. J Natl Cancer Inst 2008; 100: 1707-16. [CrossRef]

11. Frumovitz M, Singh DK, Meyer L, Smith DH, Wetheim I, Resnik E, et al. Predictors of final histology in patients with endometrial cancer. Gynecol Oncol 2004; 95: 463-8. [CrossRef]

12. Eltabbakh GH, Shamonki J, Mount SL. Surgical stage, final grade, and survival of women with endometrial carcinoma whose preoperative endometrial biopsy shows well-differentiated tumors. Gynecol Oncol 2005; 99: 309-12. [CrossRef]

13. Case AS, Rocconi RP, Straugh Jr JM, Conner M, Novak L,WangW, et al. A prospective blinded evaluation of the accuracy of frozen section for the surgical management of endometrial cancer. Obstet Gynecol 2006; 108: 1375-9. [CrossRef]

14. Kang WD, Kim CH, Cho MK, Kim JW, Kim YH, Choi HS, et al. Lymphadenectomy for low-risk endometrial cancer based on preoperative and intraoperative assessments. Int J Gynecol Cancer. 2009; 19: 657-61. [CrossRef]

15. Leitao MM, Kehoe S, Barakat RR, Alektiar K, Gattoc LP, Rabbitt C, et al. Comparison of D\&C and office endometrial biopsy accuracy in patients with FIGO grade 1 endometrial adenocarcinoma Gynecol Oncol 2009; 113: 105-8. [CrossRef]

16. Benedet JL, Bender H, Jones H 3rd, Ngan HY, Pecorelli S. FIGO staging classifications and clinical practices guidelines in management of gynecologic cancers. Int J Gyneacol Obstet 2000; 70: 20962. [CrossRef]

17. Mariani A, Webb MJ, Keeney GL, Haddock MG, Calori G, Podratz KC. Low-risk corpus cancer: is lymphadenectomy or radiotherapy necessary? Am J Obstet Gynecol. 2000; 182: 1506-19. [CrossRef]

18. Larson DM, Johnson KK, Broste SK, Krawisz BR, Kresl JJ. Comparison of $\mathrm{D} \& \mathrm{C}$ and office endometrial biopsy in predicting final histopathologic grade in endometrial cancer. Obstet Gynecol 1995; 86: 38-42. [CrossRef]

19. Obermair A, Geramou M, Gucer F, Denison U, Graf AH, Kapshammer E, et al. Endometrial cancer: accuracy of the finding of a well differentiated tumor at dilatation and curettage compared to the findings at subsequent hysterectomy. Int J Gynecol Cancer 1999; 9: 383-6. [CrossRef]

20. Wang X, Zhang H, Di W, Li W. Clinical factors affecting the diagnostic accuracy of assessing dilation and curretage vs frozen section specimen for histologic grade and depth of myometrial invasion in endometrial carcinoma. Am J Obstet Gynecol 2009; 201: 194. e1-e10. 